\title{
Front Matter: Volume 8643
}

, "Front Matter: Volume 8643," Proc. SPIE 8643, Advances in Display Technologies III, 864301 (14 March 2013); doi: 10.1117/12.2022358

SPIE. Event: SPIE OPTO, 2013, San Francisco, California, United States 


\title{
PROCEEDINGS OF SPIE
}

\section{Advances in Display Technologies III}

\author{
Liang-Chy Chien \\ Sin-Doo Lee \\ Ming Hsien Wu \\ Editors
}

6-7 February 2013

San Francisco, California, United States

Sponsored and Published by

SPIE 
The papers included in this volume were part of the technical conference cited on the cover and title page. Papers were selected and subject to review by the editors and conference program committee. Some conference presentations may not be available for publication. The papers published in these proceedings reflect the work and thoughts of the authors and are published herein as submitted. The publisher is not responsible for the validity of the information or for any outcomes resulting from reliance thereon.

Please use the following format to cite material from this book:

Author(s), "Title of Paper," in Advances in Display Technologies III, edited by Liang-Chy Chien, Sin-Doo Lee, Ming Hsien Wu, Proceedings of SPIE Vol. 8643 (SPIE, Bellingham, WA, 2013) Article CID Number.

ISSN: 0277-786X

ISBN: 9780819494122

Published by

SPIE

P.O. Box 10, Bellingham, Washington 98227-0010 USA

Telephone +1 3606763290 (Pacific Time) · Fax +1 3606471445

SPIE.org

Copyright (C) 2013, Society of Photo-Optical Instrumentation Engineers.

Copying of material in this book for internal or personal use, or for the internal or personal use of specific clients, beyond the fair use provisions granted by the U.S. Copyright Law is authorized by SPIE subject to payment of copying fees. The Transactional Reporting Service base fee for this volume is $\$ 18.00$ per article (or portion thereof), which should be paid directly to the Copyright Clearance Center (CCC), 222 Rosewood Drive, Danvers, MA 01923. Payment may also be made electronically through CCC Online at copyright.com. Other copying for republication, resale, advertising or promotion, or any form of systematic or multiple reproduction of any material in this book is prohibited except with permission in writing from the publisher. The CCC fee code is 0277-786X/13/\$18.00.

Printed in the United States of America.

Publication of record for individual papers is online in the SPIE Digital Library.

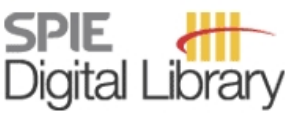

SPIEDigitallibrary.org

Paper Numbering: Proceedings of SPIE follow an e-First publication model, with papers published first

online and then in print and on CD-ROM. Papers are published as they are submitted and meet publication criteria. A unique, consistent, permanent citation identifier (CID) number is assigned to each article at the time of the first publication. Utilization of CIDs allows articles to be fully citable as soon as they are published online, and connects the same identifier to all online, print, and electronic versions of the publication. SPIE uses a six-digit CID article numbering system in which:

- The first four digits correspond to the SPIE volume number.

- The last two digits indicate publication order within the volume using a Base 36 numbering

system employing both numerals and letters. These two-number sets start with 00, 01, 02, 03, 04, $05,06,07,08,09,0 A, 0 B \ldots$. 0Z, followed by 10-1Z, 20-2Z, etc.

The CID Number appears on each page of the manuscript. The complete citation is used on the first page, and an abbreviated version on subsequent pages. Numbers in the index correspond to the last two digits of the six-digit CID Number. 


\section{Contents}

$\checkmark$ Conference Committee

vii Group IV photonics for the mid infrared (Plenary Paper) [8629-1]

$R$. Soref, The Univ. of Massachusetts at Boston (United States)

xxiii Light in a twist: optical angular momentum (Plenary Paper) [8637-2]

M. J. Padgett, Univ. of Glasgow (United Kingdom)

864302 Aerial LED signage by use of crossed-mirror array (Invited Paper) [8643-1]

H. Yamamoto, R. Kujime, H. Bando, S. Suyama, Univ. of Tokushima (Japan)

864303 Real-time pickup and display integral imaging system without pseudoscopic problem [8643-2]

J. Kim, J. -H. Jung, B. Lee, Seoul National Univ. (Korea, Republic of)

864305 Measurement of the optical characteristics of electrowetting prism array for threedimensional display [8643-4]

Y. Kim, Y. -S. Choi, K. Choi, Y. Kwon, J. Bae, A. Morozov, H. -S. Lee, Samsung Advanced Institute of Technology (Korea, Republic of)

864306 Curved transflective holographic screens for head-mounted display [8643-5]

M. Guillaumée, S. P. Vahdati, E. Tremblay, A. Mader, V. J. Cadarso, J. Grossenbacher,

J. Brugger, Ecole Polytechnique Fédérale de Lausanne (Switzerland); R. Sprague, Innovega Inc. (United States); C. Moser, Ecole Polytechnique Fédérale de Lausanne (Switzerland)

864307 High-power, red-emitting DBR-TPL for possible 3d holographic or volumetric displays [8643-6]

D. Feise, C. Fiebig, G. Blume, J. Pohl, B. Eppich, K. Paschke, Ferdinand-Braun-Institut (Germany)

\section{SESSION 2 MICRO, PROJECTION, AND OTHER DISPLAYS}

864308 Direct integration of a 4-pixel emissive display into a knit fabric matrix [8643-7]

J. P. Coyle, B. Li, G. Dion, A. K. Fontecchio, Drexel Univ. (United States)

864309 A CMOS microdisplay with integrated controller utilizing improved silicon hot carrier luminescent light sources [8643-8]

P. J. Venter, Univ. of Pretoria (South Africa); A. C. Alberts, INSiAVA (Pty) Ltd. (South Africa);

M. du Plessis, Univ. of Pretoria (South Africa); T. -H. Joubert, M. E. Goosen,

C. Janse van Rensburg, P. Rademeyer, N. M. Fauré, INSiAVA (Pty) Ltd. (South Africa) 
$86430 \mathrm{~A}$ Effect of nanodroplet ink concentration on switching response of reverse-emulsion electrophoretic displays [8643-9]

W. K. Wang, San José State Univ. (United States); R. Cromer, Zikon, Inc. (United States);

M. Goedert, M. Mobed-Miremadi, S. -J. Lee, San José State Univ. (United States)

8643 OB Microlens array based LCD projection display with software-only focal distance control [8643-10]

M. Sieler, P. Schreiber, A. Bräuer, Fraunhofer Institute for Applied Optics and Precision Engineering (Germany)

\section{SESSION $3 \quad$ DISPLAY COMPONENTS}

8643 OC Compact laser module with a high-speed liquid crystal attenuator for see-through display applications [8643-11]

T. Takeishi, M. Ide, S. Fukaya, S. Katoh, T. Nozaki, Citizen Holdings Co., Ltd. (Japan)

8643 OD Design concept of an FLC-NLC combined circular polarization switch for 3D laser picoprojectors [8643-13]

S. Kato, T. Takeishi, T. Nozaki, M. Ide, Citizen Holdings Co., Ltd. (Japan)

8643 OF A passive cooling system proposal for multifunction and high-power displays [8643-14] I. Tari, Middle East Technical Univ. (Turkey)

\section{POSTER SESSION}

$86430 \mathrm{~J}$ Estimation of true radiance and sub pixel position of saturated point targets [8643-18] E. Avrahamov, N. Shavit, Elisra Electronic Systems, Inc. (Israel); Z. Zalevsky, Bar-llan Univ. (Israel)

8643 OK Scene-based nonuniformity correction algorithm based on optical flow [8643-19] C. Peng, Q. Chen, Nanjing Univ. of Science and Technology (China); T. Zhao, Xi'an Sicong Chuangwei Opto-Electronic Co., Ltd. (China); F. Xu, W. Qian, Nanjing Univ. of Science and Technology (China)

$8643 \mathrm{OL}$ The Influence of $\mathrm{pH}$ of the precursor solution on $\mathrm{TiO}_{2}$ films under hydrothermal synthesis [8643-20]

L. Xia, Z. H. Feng, H. T. Dai, S. G. Wang, Tianjin Univ. (China); X. W. Sun, South Univ. of Science and Technology of China (China)

$8643 \mathrm{OM}$ Lateral ink mobility and fringe field effects across the porous matrix of an electrophoretic display [8643-21]

K. Li Tsui, M. Ahumada, San José State Univ. (United States); M. Bryning, Zikon, Inc. (United States); M. Hartono, S. - J. J. Lee, San José State Univ. (United States)

Author Index

iv 


\section{Conference Committee}

Symposium Chair

David L. Andrews, University of East Anglia Norwich (United Kingdom)

Symposium Cochairs

Alexei L. Glebov, OptiGrate Corporation (United States)

Klaus P. Streubel, OSRAM GmbH (Germany)

Program Track Chair

Liang-Chy Chien, Kent State University (United States)

Conference Chairs

Liang-Chy Chien, Kent State University (United States)

Sin-Doo Lee, Seoul National University (Korea, Republic of)

Ming Hsien Wu, Hamamatsu Corporation (United States)

Conference Program Committee

Karlheinz Blankenbach, Pforzheim Universität (Germany)

Pierre M. Boher, ELDIM (France)

Cheng-Huan Chen, National Tsing Hua University (Taiwan)

Chin Hsin Chen, National Chiao Tung University (Taiwan)

Janglin Chen, Industrial Technology Research Institute (Taiwan)

Jurgen H. Daniel, Palo Alto Research Center, Inc. (United States)

Paul S. Drzaic, Apple Inc. (United States)

Mark Finn, Veritas et Visus (United States)

Norbert Fruehauf, Universität Stuttgart (Germany)

Nobuyuki Hashimoto, Citizen Holdings Company Ltd. (Japan)

Klaus Hecker, Verband Deutscher Maschinen-und Anlagenbau e. V. (Germany)

Jason C. Heikenfeld, University of Cincinnati (United States)

Alex Henzen, IRX-Innovations B.V. (Netherlands)

Yi-Pai Huang, National Chiao Tung University (Taiwan)

Koichi Kanzaki, Consultant (Japan)

Takashi Kitamura, Chiba University (Japan)

Lachezar Komitov, Göteborg Universitet (Sweden)

Byoungho Lee, Seoul National University (Korea, Republic of)

Kars-Michiel H. Lenssen, Philips Research Nederland B.V.

(Netherlands)

Akihiro Mochizuki, i-CORE Technology, LLC (United States)

Keith Rollins, DuPont Teijin Films U.K. Ltd. (United Kingdom) 
Ryo Sakurai, Bridgestone Corporation (Japan)

Robert A. Sprague, SiPix Imaging Inc. (United States)

Andrew J. Steckl, University of Cincinnati (United States)

Christopher Williams, Logystyx UK Ltd. (United Kingdom)

Michael Wittek, Merck KGaA (Germany)

Pochi Yeh, University of California, Santa Barbara (United States)

Tae-Hoon Yoon, Pusan National University (Korea, Republic of)

\section{Session Chairs}

1 3D Displays

Ming Hsien Wu, Hamamatsu Corporation (United States)

2 Micro, Projection, and Other Displays

Ming Hsien Wu, Hamamatsu Corporation (United States)

3 Display Components

Ming Hsien Wu, Hamamatsu Corporation (United States)

4 Organic Light-Emitting Diodes

Liang-Chy Chien, Kent State University (United States) 